\title{
The Influence of Mixed Cationic and Anionic Surfactants on the Flotation of Nepheline
}

\author{
${ }^{1}$ Nikolay Afanasievich Shapovalov, ${ }^{1}$ Andrey Ivanovich Gorodov, \\ ${ }^{1}$ Anatoly Anatolyevich Krainiy and ${ }^{2}$ ElenaVladimirovna Krainiaia \\ ${ }^{1}$ Department of Theoretical and Applied Chemistry, \\ Belgorod State Technological University named after V.G. Shukhov, Belgorod, Russia \\ ${ }^{2}$ Belgorod State National Research University, Belgorod, Russia
}

\begin{abstract}
The nepheline-containing raw materials is studied. As a result of studies it is suggested that a mixed consisting of anionic and cationic surfactants can be used as a collector for reverse flotation of nepheline. Based on studies micelle formation of anionic surfactants (Soaps of Tall Oils of Deciduous (STOD) and coniferous (STOC) wood) and cationic surfactants (FLON-1) and their mixtures justified the optimal ratio of components in the compositions. The effect of anionic and cationic surfactants and their mixtures on wetting and zeta-potential of mineral surfaces was studied. Laboratory tests were carried out on the flotation machine to determine the optimal conditions for flotation of nepheline-containing raw materials. The composition of the collector mixture, the optimal consumption of reagents has been established. The efficiency is best of the collector in flotation of nepheline ores was a mixed of $80 \%$ STOD $+20 \%$ FLON-1
\end{abstract}

Key words: Fotation, collector, anionic, cationic, surfactants mixed of anionic and cationic surfactants, micelle, aluminum, tailing, nepheline concentrate

\section{INTRODUCTION}

The stocks of high-quality aluminum raw materials in Russia are insufficient to meet the industrial needs of the country. Two thirds of the alumina needed for aluminum production is imported from abroad. At the same time, Russia has a very large base of low-quality aluminum raw materials (nepheline ores, leucitite and others). To meet the demand for aluminum it is helpful to use the flotation method of enrichment. Flotation is a widespread colloid-chemical process that allows the enrichment of non-magnetic and finely disseminated ores of complex material composition which are difficult to process (enrich) with other methods (Shapovalov et al., 2014).

A large source for the potential production of alumina is nepheline concentrate, obtained in the process of complex enrichment of the largest deposit of apatite-nepheline ores of the Khibiny Massif located in the central part of the Kola Peninsula. Mining and processing of apatite-nepheline ore is carried out by Apatite AO company. The company produces apatite, sphenic, aegirin, titanomagnetite and nepheline concentrates. Currently, the volume of production of nepheline concentrate $\left(\sim 28.5 \pm \quad 0.5 \% \quad \mathrm{Al}_{2} \mathrm{O}_{3}\right)$ from apatite-nepheline ore is $1.1 \mathrm{mln}$.tons/year. In the context of continuous decline in the quality of ore these are the main tasks in the production of nepheline concentrate: ensuring its quality and developing modes of more economical operation. One of the ways to improve the quality of nepheline concentrate is to increase the selective ability of the collecting mixture in relation to dark-colored minerals (pyroxene, aegirine, biotite, titanite) (Muhina, 2004). Thus, research aimed at developing new flotation reagents and optimizing reagent flotation modes in the process of aluminum-containing ores enrichment is relevant. Since, most collectors are represented by surface-active materials (surfactants) their selectivity and flotation activity depend on the colloidal-chemical properties of the surfactants used. One way to affect the technological properties of collectors is creating surfactant mixtures. Mixed consisting of cationic and anionic surfactants are of particular interest. Changing the ratio of components, one can adjust the technological properties of collectors in a wide range. Thus, a promising direction for increasing the efficiency of flotation of aluminum-containing ores is the use of collecting mixtures consisting of cationic and anionic surfactants.

Currently, anion-active surfactants, i.e., tall oil soaps are used for the flotation of nepheline ores (Lygach et al, 2007). Among most commonly used cationic collectors are amines, primary amine esters, diamines and their esters.

Corresponding Author: Nikolay Afanasievich Shapovalov, Department of Theoretical and Applied Chemistry, Belgorod State Technological University named after V.G. Shukhov, Belgorod, Russia 


\section{MATERIALS AND METHODS}

Method of reverse flotation was used in the work to obtain nepheline concentrate. Laboratory studies were carried out on a Flotation Machine FM-3 according to, the scheme shown in Fig. 1. The target product (concentrate) is a flotation tail.

The volume of the flotation cell of the main and control flotation is $1 \mathrm{dm}^{3}$, the impeller speed is $1480-1500$ $\mathrm{rpm}$, the air consumption is $1.26 \mathrm{dm}^{3} / \mathrm{min}$. Sodium hydroxide was used as a medium regulator (pulp pH 11.6). To intensify the process and improve the concentrate quality Calcium Chloride $\left(\mathrm{CaCl}_{2}\right)$ was used as it activates the surface of dark-colored minerals and contributes to an increase in the fixing strength of the collector (Muhina, 2004). Chemical and mineralogical analysis of raw materials and flotation products was carried out on an ARL 9900 WorkStation instrument with an integrated diffraction system. The granulometric composition was determined by laser granulometry using an Analysette 22 NanoTec plus instrument. Analytical studies of the raw material microstructure were carried out using a TESCAN MIRA 3 LMU scanning electron microscope with an $\mathrm{X}$-ray emission microprobe. The specific electrical conductivity of surfactant solutions was found using an EXPERT-002 conductometer. To assess the effect of collectors on the wetting of mineral surfaces, measurements of the wetting edge angle were made using the KRUSS DSA30 device. The experiments were carried out on minerals with polished surface, washed with warm chrome mixture and distilled water. The zeta-potentials of the minerals were measured using a zeta-potential analyzer (Zetatrac Microtrac). A $30 \mathrm{mg}$ of each sample with particle size being $<20 \mu \mathrm{m}$ was placed in a $50 \mathrm{~cm}^{3}$ beaker and then $40 \mathrm{~cm}^{3}$ of deionized water was added into the beaker, followed by addition of reagents one by one. The pulp was allowed to stand for $3 \mathrm{~min}$ after being agitated using a magnetic stirrer for $5 \mathrm{~min}$ and the supernatant was taken for the zeta potential measurement. Three replicates were taken and the average was reported. The metrological support of the tests was performed in accordance with the requirements to the quality of nepheline concentrate of the Apatite AO Company standard.

Main part: A representative sample of apatite flotation tails (Nepheline Flotation Feeding (NFF)) from the Apatite $\mathrm{AO}$ apatite-nepheline processing plant (ANOF-3) prepared for nepheline flotation was used as the starting material. Chemical and mineralogical compositions are given in Table 1, 2 and Fig. 2. Studies of particle size distribution (Fig. 3) have shown that the average particlesizeis 100-200 $\mu \mathrm{m}$. Individual grains (up to $40 \%$ ) have sizes from 1-30 $\mu \mathrm{m}$.

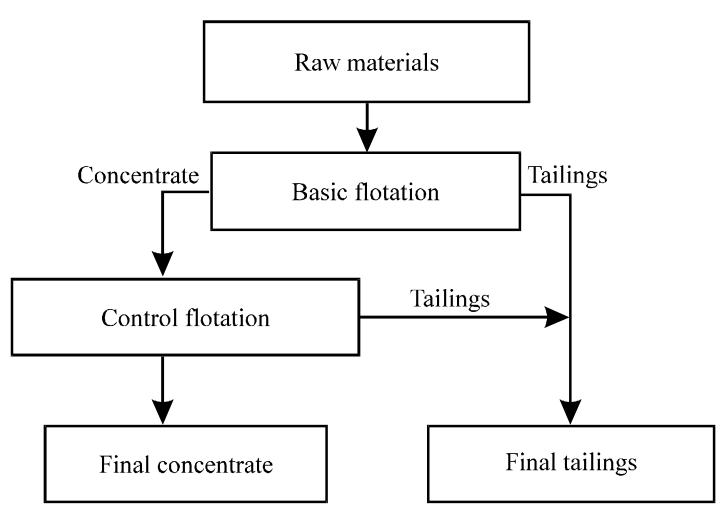

Fig. 1: Laboratory flotation scheme

The results of X-ray micro probe analysis of the elemental composition presented as spectra of the powder surface at different points (Fig. 4, Table 3) confirm that NFF grains are represented by nepheline minerals (spectrum 3) feldspar (spectrum 1, 5) dark colored minerals (spectrum 2,4). The particles consist of both monomineral and polymineral aggregates. Monomineral aggregate grains consist predominantly of dark-colored minerals of a somewhat elongated shape with a pronounced shell-like fracture and a rough surface. But most often polymineral aggregates are found consisting of particles of nepheline, feldspar and other minerals (Fig. 5).

Currently, nepheline flotation is carried out using a mixture of saponified tall oils as a collecting reagent. Tall oils are a complex mixture of organic compounds, the main ones being salts of fatty and resin acids as well as unsolvable substances-sterols and aliphatic alcohols. The use of tall oils in the nepheline flotation cycle requires a large amount of reagent (1000-2000 g/t). But even the extra high supply of the collecting mixture does not always allow to obtain high-quality nepheline concentrate, since, it is difficult-to-enrich ores that are involved into processing (Lygach et al., 2007).

According to, NFF studies it can be assumed that a mixture consisting of anionic and cationic surfactants can be used as a collecting mixture for reverse flotation of nepheline. A multi-mineral system is characterized by presence of grains with different surface areas (both in form and chemical composition) and accordingly has different adsorption centers. Thus, mixed of anionic and cationic surfactants can be adsorbed on positively and negatively charged surface areas of complex mineral systems.

In laboratory conditions, compositions based on anionic and cationic surfactants were investigated. Soaps of Tall Oils of Deciduous (STOD) and coniferous (STOC) 
Table 1: The chemical composition of NFF (\%)

\begin{tabular}{|c|c|c|c|c|c|c|c|c|c|}
\hline $\mathrm{SiO}_{2}$ & $\mathrm{Al}_{2} \mathrm{O}_{3}$ & $\mathrm{Na}_{2} \mathrm{O}$ & $\mathrm{K}_{2} \mathrm{O}$ & $\mathrm{Fe}_{2} \mathrm{O}_{3}$ & $\mathrm{MgO}$ & $\mathrm{CaO}$ & $\mathrm{TiO}_{2}$ & $\mathrm{P}_{2} \mathrm{O}_{5}$ & Other \\
\hline $43.1 \pm 1$ & $23.8 \pm 1$ & $15.6 \pm 1$ & $3.7 \pm 0.5$ & $5.4 \pm 0.5$ & $2.9 \pm 0.3$ & $2.4 \pm 0.3$ & $1.4 \pm 0.3$ & $1.2 \pm 0.3$ & $0.6 \pm 0.1$ \\
\hline
\end{tabular}

Table 2: Mineralogical compositions of NFF (\%)

\begin{tabular}{llllll}
\hline Nepheline & Orthoclase & Anorthite & Albite & Biotite & Titanite \\
\hline$(\mathrm{Na}, \mathrm{K}) \mathrm{AlSiO}$ & $\mathrm{KalSi}_{3} \mathrm{O}_{8}$ & $\mathrm{CaAl}_{2} \mathrm{Si}_{2} \mathrm{O}_{8}$ & $\mathrm{NaAlSi}_{3} \mathrm{O}_{8}$ & $\mathrm{~K}(\mathrm{MgFe})_{3} \mathrm{Si}_{3}\left[\mathrm{AlO}_{10}\right][\mathrm{OH}, \mathrm{F}]_{2}$ & $\mathrm{CaTiSiO}$ \\
$\mathbf{3 3 . 0 \pm 2}$ & $36.1 \pm 2$ & $10.4 \pm 1$ & $10.0 \pm 1$ & $10.2 \pm 1$ & $0.3 \pm 0.1$ \\
\hline
\end{tabular}

Table 3: The elemental composition of the NFF powder surface at different points

\begin{tabular}{|c|c|c|c|c|c|c|}
\hline Elements (\%) & Spectrum 1 & Spectrum 2 & Spectrum 3 & Spectrum 4 & Spectrum 5 & Spectrum 6 \\
\hline $\mathrm{O}$ & 40.3 & 16.4 & 37.3 & 26.2 & 43.5 & 45.7 \\
\hline $\mathrm{Al}$ & 0.8 & 1.6 & 19.2 & 2.9 & 0.6 & 5.90 \\
\hline $\mathrm{Si}$ & 24.5 & 3.0 & 22.5 & 12.9 & 24.1 & 14.2 \\
\hline $\mathrm{Na}$ & 6.5 & 2.4 & 10.9 & 2.9 & 2.2 & 1.80 \\
\hline K & 0.1 & 1.6 & 8.1 & 2.8 & & 4.80 \\
\hline $\mathrm{Fe}$ & 18.1 & 38.8 & 2.0 & 4.2 & 10.0 & 25.8 \\
\hline $\mathrm{Ti}$ & 1.2 & 34.9 & & 27.3 & 0.3 & \\
\hline P & & 0.1 & & & & 0.10 \\
\hline $\mathrm{Ca}$ & 6.1 & 0.8 & & 19.6 & 13.1 & 0.60 \\
\hline $\mathrm{Mg}$ & 2.4 & 0.4 & & 1.2 & 6.2 & 1.10 \\
\hline
\end{tabular}

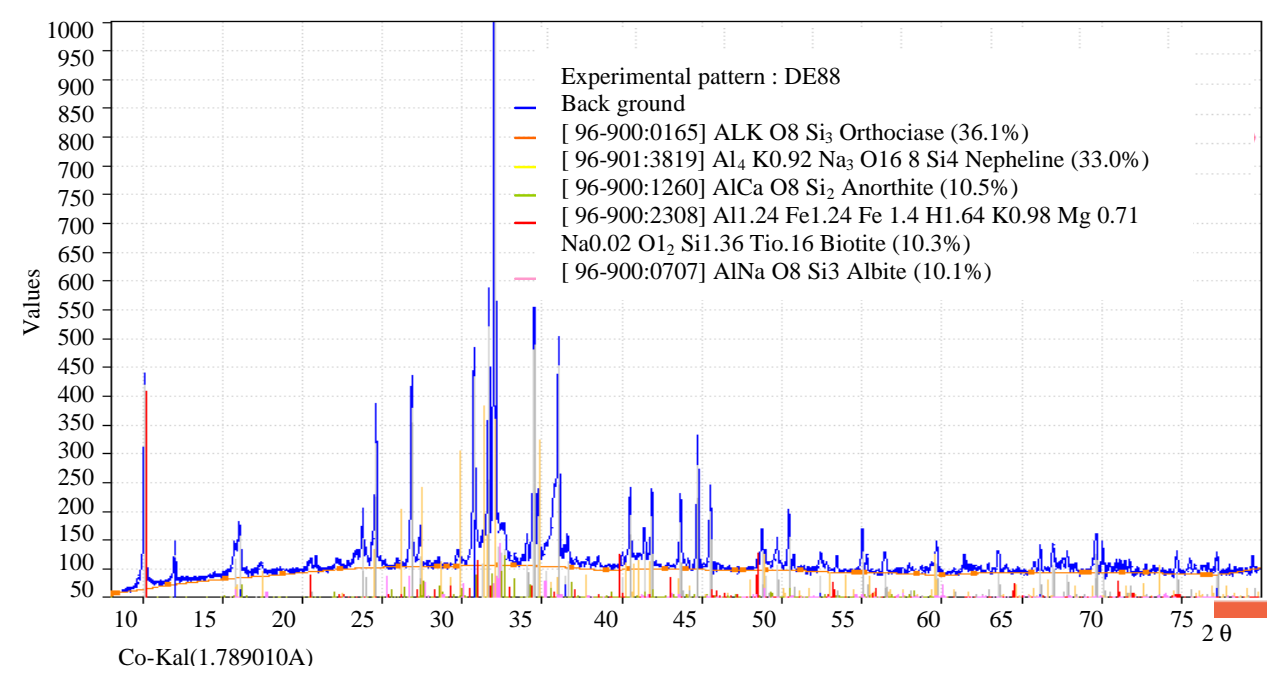

Fig. 2: XRD diffraction of NFF

wood species were chosen as anti-surfactants as currently for the flotation of nepheline, their mixture is used in the ratio of $80: 20$, respectively. The domestic nitrogen-containing collector FLON-1 was selected as a cationic surfactant (joint development of the research and production enterprise RPE Khimprom servis $\mathrm{OOO}$ and BSTU named after V.G. Shukhov) as it exhibits high selectivity towards silicon oxide (Shapovalov et al., 2017). FLON-1 belongs to the third class of danger and has a high degree of bio-diversity (85-90\%).

The interaction of surfactant molecules in the solution volume was evaluated using the value of Critical Micelle Concentration (CNM). CNM range for solutions of anionic surfactants, cationic surfactants and their mixtures, derived with a help of surface tension isotherms

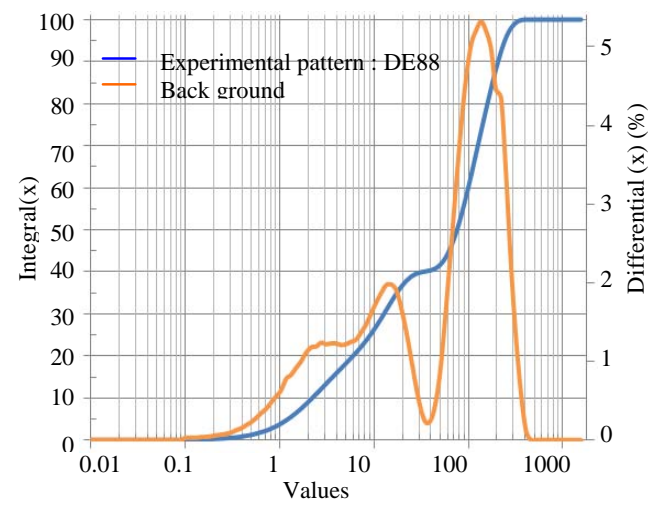

Fig. 3: Differential and integral particle size distribution of NFF 


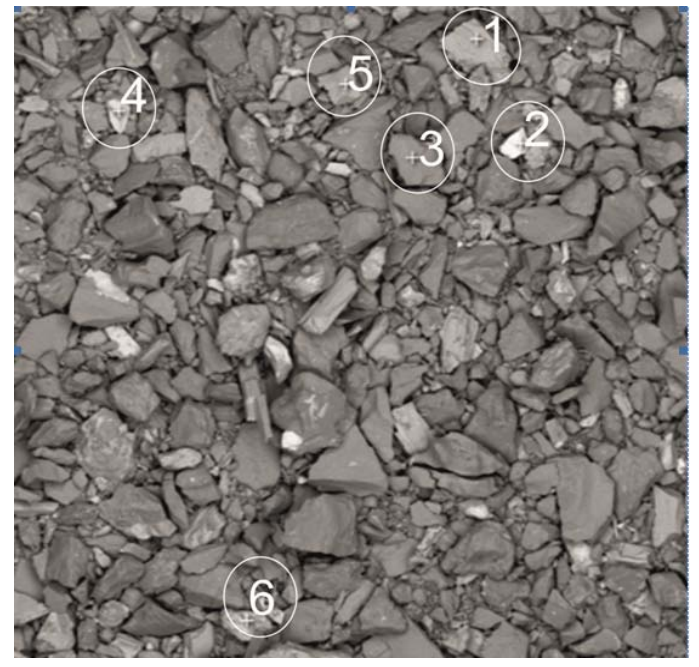

Fig. 4: Photomicrograph of NFF powder indicating points of the spectra under study

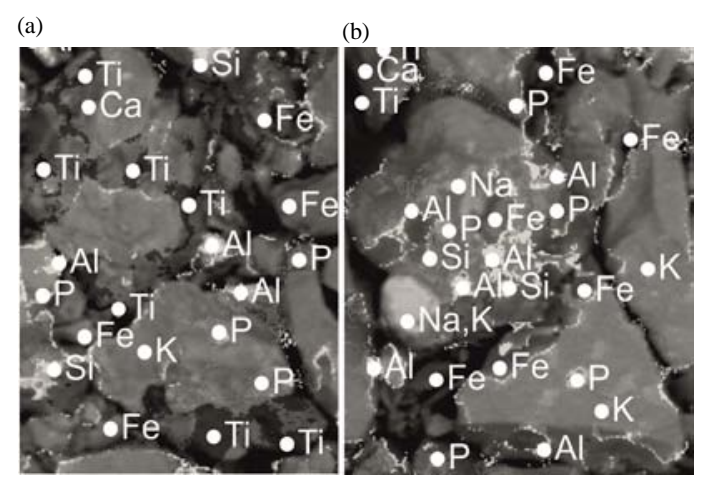

Fig. 5: a, b) Chemical elements distribution map on individual NFF grains

and data on dependence of the specific electrical conductivity on the concentration of solutions are presented in Table 4.

The data in Table 4 indicate that the values of $\mathrm{CCM}$ for STOD mixed (80)+STOC (20) and STOD (80) + FLON-1 $(20 \%)$ are slightly different and are respectively, 0.4 and $0.1 \mathrm{mg} / \mathrm{mL}$. The micelle formation processes in surfactant mixed of different nature were studied and based on the data obtained, a graph of the dependence of the CCM range on the mixture composition was constructed (Fig. 6).

As the studies show, micelles are formed at a lower concentration in a mixture of cationic and anionic surfactants. Thus, adding cationic to anionic surfactants reduces CCM. CCM values are preserved in a wide range of the ratio of components in the solution (FLON-1: STOD) from 20:80-70:30\%.

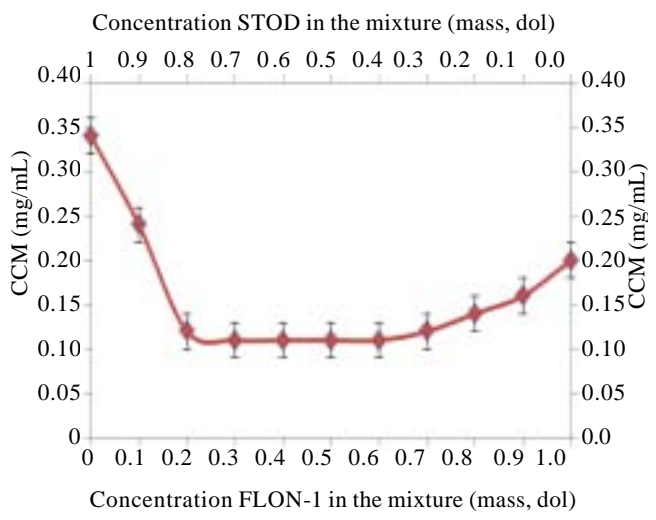

Fig. 6: Graph of the dependence of the CMF range on the mixture composition

The behavior of the mixture consisting of cationic and anionic surfactants is due to the strong electrostatic interaction of oppositely charged surfactant ions and the formation of a new substance a stable ionic associate which is called a catanionic surfactant (Tomasic et al., 1999; Tsuchiya et al., 2007). The interaction of tall oil soaps and FLON-1 can be given by the reaction equation as follows:

$$
\begin{aligned}
& \mathrm{R}_{1} \mathrm{COONa}+\mathrm{R}_{2}-\mathrm{NH}_{3}-\underset{\mathrm{O}}{\mathrm{O}-\mathrm{CH}_{3}} \rightarrow \mathrm{R}_{1} \mathrm{COONH_{3 }}-\mathrm{R}_{2}+ \\
& +\mathrm{CH}_{3} \mathrm{COONA}
\end{aligned}
$$

Where:

$\mathrm{R}_{1}=$ Radical of the main components of tall oil soaps

$\mathrm{R}_{2}=$ Radical of the main components of FLON-1

The resulting substances are constituted to a large extent by hydrocarbons and therefore, tend to aggregate making a separate phase. The states of the system at different ratios of components were observed visually. For example in the mixture of STOD $(65 \%)+$ FLON-1 (35\%) the formation of flakes was observed which float up in a time forming a film. The system FLON-1 (20\%)+STOD $(80 \%)$ is a highly opalescent liquid that does not form a film. Therefore, for further studies, the ratio FLON-1: STOD 20:80\% was chosen at which CMF decreases and the aggregate stability of the mixture is preserved.

Since, the process of foam flotation occurs at the boundary of mineral-water medium-air, the study studies wetting. To assess the wetting ability of collectors, the following mineral layers were used: nepheline, albite, quartz $\left(\mathrm{SiO}_{2}\right)$, hematite $\left(\mathrm{Fe} \mathrm{O}_{3}\right.$. The values of the edge wetting angles (after $2 \mathrm{~min}$ ) of water and solutions of surface-active collectors of different concentrations on the surface of minerals are presented in the Table 5 .

Analysis of the wetting edge angles on the mineral surface (Table 5) showed that the investigated surfactants 
Table 4: CCM range of collecting solutions

\begin{tabular}{lccccc} 
Collector & STOD & STOC & FLON-1 & STOD (80\%)+STOC (20\%) & STOD (80\%)+FLON-1 (20\%) \\
\hline CCM $(\mathrm{mg} / \mathrm{mL})$ & 0.3 & 0.4 & 0.2 & 0.4 & 0.1 \\
\hline
\end{tabular}

Table 5: The values of the contact angle of wetting $\left(^{\circ}\right)$

\begin{tabular}{|c|c|c|c|c|c|c|c|c|c|c|c|}
\hline \multicolumn{12}{|c|}{ Collector $\left(\mathrm{g} / \mathrm{dm}^{3}\right)$} \\
\hline \multicolumn{4}{|c|}{ STOD } & \multicolumn{4}{|c|}{ FLON-1 } & \multicolumn{4}{|c|}{ STOD+FLON-1 } \\
\hline 0.1 & 0.2 & 0.4 & 0.6 & 0.1 & 0.2 & 0.4 & 0.6 & 0.1 & 0.2 & 0.4 & 0.6 \\
\hline \multicolumn{12}{|c|}{ The values of the contact angle of wetting $\theta\left({ }^{\circ}\right)$} \\
\hline 80 & 44 & 42 & 32 & 68 & 64 & 63 & 39 & 42 & 37 & 37 & 32 \\
\hline 24 & 35 & 37 & 35 & 63 & 41 & 75 & 69 & 25 & 43 & 39 & 20 \\
\hline 15 & 11 & 13 & 13 & 40 & 26 & 30 & 24 & 13 & 16 & 18 & 18 \\
\hline 54 & 52 & 49 & 46 & 20 & 36 & 54 & 27 & 42 & 52 & 48 & 41 \\
\hline
\end{tabular}

Table 6: Zeta-potential of NFF

\begin{tabular}{llllll}
\hline Collector* & Without reagent & STOD & STOD+STOC & STOD +FLON-1 & FLON-1 \\
\hline Zeta-potential $(\mathrm{mV})$ & -24.8 & -44.4 & -35.2 & +44.7 & +18.8 \\
\hline
\end{tabular}

*Concentration of collectors $200 \mathrm{mg} / \mathrm{dm}^{3}$

and their mixture, depending on the nature of the mineral can act as a collector that reduces wettability of the hydrophilic mineral and as a wetting agent that increases wetting of the hydrophobic mineral surface with water.

The surface of nepheline is hydrophobic $\left(\theta>90^{\circ}\right)$. Assessing the degree of hydrophilization of nepheline by collectors it can be seen that a mixture of STOD+FLON-1 and STOD at concentrations of $0.2-0.6 \mathrm{~g} / \mathrm{dm}^{3}$, equally increase the hydrophilicity of nepheline. However, at a low concentration $\left(0.1 \mathrm{~g} / \mathrm{dm}^{3}\right)$, the STOD+FLON-1 mixture reduces the angle $\left(42^{\circ}\right)$ to a greater extent than the STOD $\left(80^{\circ}\right)$ which indicates a more active adsorption of the composite collector. FLON-1 at concentrations of $0.1-0.4 \mathrm{~g} / \mathrm{dm}^{3}$ to a lesser extent increases the hydrophilicity of the nepheline surface which will adversely affect the technological properties of the reverse flotation of nepheline-part of the target product will be carried with foam. Edge wetting angles on the albite surface indicate that the mixture of STOD+FLON-1 in the concentration range of $0.2-0.4 \mathrm{~g} / \mathrm{dm}^{3}$ to a lesser extent increases wettability, compared with STOD which has a positive effect on the reverse flotation of nepheline. The edge wetting angles on the hematite surface by STOD and STOD + FLON-1 collectors at concentrations $0.2-0.6 \mathrm{~g} / \mathrm{dm}^{3}$ have almost the same values. However, the mixture of STOD+FLON-1 to a greater extent reduces the hydrophilicity of quartz compared to STOD.

To study the electro-surface properties, the zeta-potential studies are carried out, the results are presented in Table 6. An increase in the negative zeta-potential of anionic collectors (Table 6) indicates their adsorption in a slightly alkaline environment. The FLON-1 cationic collector is actively sorbed on the surface of the NFF while the ion adsorption is confirmed by the transition of the zeta-potential to positive values $(+18.8 \mathrm{mV})$. The value of zeta-potential when using a mixture of STOD+FLON-1 is much higher $(+44.7 \mathrm{mV})$ compared with FLON-1 this is probably due to the fact that the collector molecules are adsorbed not only in the form of ions but also in the form of micelles. Due to the big size of the micelle its positive parts are closer to the diffusion environment.

To determine the effectiveness of collecting mixtures and their optimal concentrations, a series of laboratory flotations was carried out. The efficiency of flotation enrichment was assessed by the Hankok-Luyken indicator ( $)$ which was calculated by the equation:

$$
\begin{aligned}
& \eta=\frac{\varepsilon_{\mathrm{k}}-\gamma_{\mathrm{K}}}{100-\alpha} ; \varepsilon_{\mathrm{k}}=\gamma_{\mathrm{K}} \frac{\beta_{\mathrm{k}}}{\alpha}=\frac{\alpha-\vartheta_{\mathrm{XB}}}{\beta-\vartheta_{\mathrm{XB}}} \times 100= \\
& \frac{\gamma_{\mathrm{K}}(\mathrm{g})}{\gamma_{\mathrm{K}}(\mathrm{g})+\gamma_{\mathrm{XB}}(\mathrm{g})} \times 100 ; \gamma_{\mathrm{XB}}=100-\gamma_{\mathrm{Xk}}
\end{aligned}
$$

Where:

$\varepsilon_{\mathrm{k}}=$ The $\mathrm{Al}_{2} \mathrm{O}_{3}$ recovery into headings (\%)

$\gamma_{\mathrm{k}} \quad=$ Concentrate yield $(\%)$

$\gamma_{\mathrm{k}}(g) \quad=$ Headings bulk $(\mathrm{g})$

$\gamma_{\mathrm{XB}} \quad=$ Froth product (tails) yield $(\%)$

$\gamma_{\mathrm{kB}}(g)=$ Froth product bulk $(\mathrm{g})$

$\alpha, \beta_{\mathrm{k}}, \partial_{\mathrm{XB}} \alpha, \beta=$ The $\mathrm{Al}_{2} \mathrm{O}_{3}$ concentration in the starting product, the concentrate and the tails, respectively

The experimental results are shown in Table 7 and Fig. 7. An inverse relationship is observed when using the collecting mixture STOD $(80 \%)+$ STON $(20 \%)$ a reduction in consumption of $2000-1000 \mathrm{~g} / \mathrm{t}$ significantly reduces the extraction of $\mathrm{Al}_{2} \mathrm{O}_{3}$ in the concentrate with a slight change in the quality of the concentrate and at a consumption of $<800 \mathrm{~g} / \mathrm{t}$ it does not allow to obtain any conditioned nepheline concentrate. Thus, the most effective collecting mixture considering the consumption is the one composed of $80 \%$ STOD $+20 \%$ FLON-1 with the required concentrate 
Table 7: Laboratory flotation results

\begin{tabular}{|c|c|c|c|c|c|c|}
\hline \multirow[b]{2}{*}{ Collector } & \multirow{2}{*}{$\begin{array}{l}\text { Consumption of } \\
\text { the collector }(\mathrm{g} / \mathrm{t})\end{array}$} & \multicolumn{4}{|c|}{ Technological parameters } & \multirow[b]{2}{*}{$\eta$} \\
\hline & & $y_{K}(\%)$ & $\beta_{K}(\%)$ & $\varepsilon_{k}(\%)$ & $\partial_{\mathrm{KB}}(\%)$ & \\
\hline $80 \%$ STOD $+20 \%$ STOC & 2000 & 53 & 28.75 & 64.1 & 18.24 & 0.14 \\
\hline $80 \%$ STOD $+20 \%$ STOC & 1500 & 48 & 28.38 & 57.2 & 19.56 & 0.12 \\
\hline $80 \%$ STOD $+20 \%$ STOC & 1000 & 46 & 28.15 & 54.4 & 20.08 & 0.11 \\
\hline $80 \%$ STOD $+20 \%$ STOC & 800 & 45 & 27.42 & 51.9 & 20.82 & 0.09 \\
\hline FLON-1 & 300 & 67 & 22.69 & 63.9 & 20.99 & -0.10 \\
\hline $80 \%$ STOD $+20 \%$ FLON -1 & 1000 & 52 & 28.49 & 62.6 & 18.64 & 0.14 \\
\hline $80 \%$ STOD $+20 \%$ FLON -1 & 500 & 65 & 28.17 & 76.6 & 15.76 & 0.16 \\
\hline $80 \%$ STOD $+20 \%$ FLON -1 & 400 & 63 & 27.82 & 73.7 & 16.92 & 0.14 \\
\hline $80 \%$ STOD $+20 \%$ FLON -1 & 500 (on the back of the water) & 62 & 28.27 & 73.8 & 16.24 & 0.16 \\
\hline $90 \%$ STOD $+10 \%$ FLON -1 & 500 & 61 & 28.52 & 72.7 & 16.51 & 0.16 \\
\hline $65 \%$ STOD $+35 \%$ FLON- 1 & 500 & 63 & 27.95 & 73.9 & 16.74 & 0.14 \\
\hline
\end{tabular}

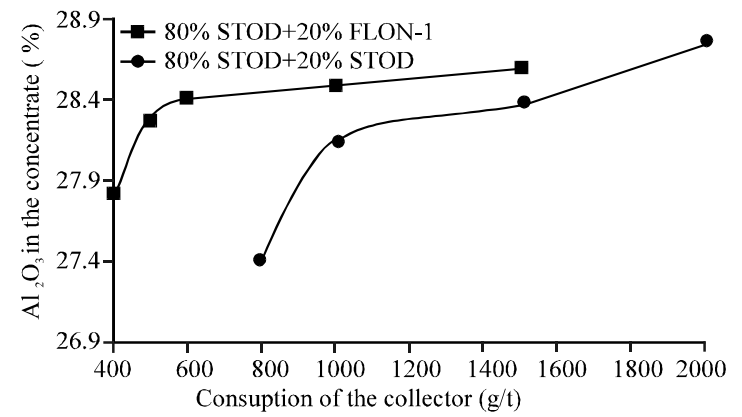

Fig. 7: Graph of $\mathrm{Al}_{2} \mathrm{O}_{3}$ content in concentrate versus collector consumption

quality being achieved at a rate of $500-600 \mathrm{~g} / \mathrm{t}$ which is up to 3 times less than when using STOD $(80 \%)+$ STOS $(20 \%)$. Note that in a number of experiments, the concentrate yield is more than $60 \%$ and the $\mathrm{Al}_{2} \mathrm{O}_{3}$ extraction degree is more than $70 \%$ which is not achieved using STOD $(80 \%)+$ STOC $(20 \%)$. The use of recycled water during flotation with a mixture of $80 \%$ STOD $+20 \%$ FLON-1 has a positive effect on the final properties of the concentrate obtained, increasing the production maintainability and reducing the environmental burden on the nearby area.

\section{CONCLUSION}

The most effective collecting mixture in the flotation of aluminum-containing raw materials, represented by apatite flotation wastes from the Apatite $\mathrm{AO}$ enrichment plant was a mixture of anionic and cationic surfactants $80 \%$ STOD $+20 \%$ FLON-1. This mixture has specific colloid-chemical properties compared to the original surfactants. The recommended concentration of the collecting mixture is $500-600 \mathrm{~g} / \mathrm{t}$. As a result of flotation enrichment of the starting product with a total alumina content of $23.8 \%$ using recycled water, nepheline concentrate was obtained with an $\mathrm{Al}_{2} \mathrm{O}_{3}$ content of $28.27 \%$. The concentrate yield is $62 \%$ of the mass of the initial load. The resulting concentrate meets the requirements to the quality of nepheline concentrate of the Apatite AO company standard.

\section{ACKNOWLEDGEMENTS}

The study was prepared within a development program of the Base University on the basis of BSTU named after V.G. Shukhov

\section{REFERENCES}

Lygach, V.N., G.V. Ladygina, J.E. Bryljakov and M.A. Kostrova, 2007. [Improving the efficiency of nepheline production at ANOF-I Apatit OJSC by improving the reagent regimen of reverse $\mathrm{fl}$ ot nepheline (In Russian)]. Gornyj Inf. Anal. Bjulleten, 10: 365-369.

Muhina, T.N.,n 2004. [Improving the efficiency of reverse flotation of nepheline using high molecular weight alkyl benzene sulfonates]. Ph.D Thesis, Kola Scientific Center of the Russian Academy of Sciences, Saint-Petersburg, Russia.

Shapovalov, N.A., A.A. Krayniy, A.I. Gorodov and I.S. Makuschenko, 2014. Study of the influence of different kinds of collectors and depressant flotation iron-containing minerals mikhailovsky deposit. Fundam. Res., 9: 318-323.

Shapovalov, N.A., A.I. Gorodov, A.Y. Schekina, A.A. Krayniy and L.K. Zagorodnyuk, 2017. Comprehensive use of waste after beneficiation of magnetite fraction by floatation. Adv. Eng. Res., 133: 766-772.

Tomasic, V., I. Stefanic and N. Filipovic-Vincekovic, 1999. Adsorption, association and precipitation in hexadecyltrimethylammonium bromide/sodium dodecyl sulfate mixtures. Colloid Polym. Sci., 277: 153-163.

Tsuchiya, K., J. Ishikake, T.S. Kim, T. Ohkubo and H. Sakai et al. , 2007. Phase behavior of mixed solution of a glycerin-modified cationic surfactant and an anionic surfactant. J. Colloid Interface Sci., 312: 139-145. 